\title{
Climate variations in the Circum-Alpine region and their influence on Neolithic-Bronze Age lacustrine communities: displacement and/or cultural adaptation
}

\author{
Francesco Menotti \\ Institute of Prehistory and Archaeological Science, Basel University, $\mathrm{CH}$ \\ Francesco.Menotti@unibas.ch
}

\begin{abstract}
Because of its delicate balance, the hydrological system of the Alpine region is affected immediately by climatic variations. The most obvious evidence of hydrologic instability is reflected by natural water basins in particular rivers and lakes. Caused by climate change, but catalyzed by a myriad of environmental factors, the water levels of lakes and other natural water reservoirs fluctuate, influencing people who live in their proximity. In some cases, the irregular pattern of human occupation around prehistoric Circum-Alpine lakes shows a remarkable affinity to climatic oscillations. People's responses to environmental influence are nevertheless unpredictable, and sometimes illogical.
\end{abstract}

IZVLEČEK - Na hidrološki sistem alpske regije zaradi njegovega občutlivega ravnotežja takoj vplivajo spremembe klime. Najbolj očitno se dokaz o hidrološki nestabilnosti odraža pri naravnih vodnih kotanjah in še posebej pri rekah in jezerih. Zaradi klimatskih sprememb, ki jih pospešuje nešteto okoljskih dejavnikov, nihajo vodni nivoji jezer in drugih naravnih vodnih rezervoarjev, kar vpliva na kulturne skupnosti, ki živijo v njihovi bližini. Nepravilen vzorec človeške poselitve okoli prazgodovinskih alpskih jezer $v$ nekaterih primerih kaže pomembno podobnost s klimatskimi nihanji. Vendar so človeški odgovori na okoljske vplive nepredvidljivi in včasih nelogični.

KEY WORDS - Alps; climate; Neolithic; Bronze Age; lacustrine; settlement

\section{Introduction}

Patterns of occupation have always been among the most discussed topics in Circum-Alpine lake-dwelling studies. Although the lacustrine settlement tradition perpetuated itself for more than three millennia, it was certainly not homogeneous, in terms of diachronic occupations. In fact, the lake shores were not settled continuously - phases of occupation alternated with phases of abandonment.

It has been shown that most occupational phases coincided with favorable climatic conditions (Magny 1993). However, there were periods of climatic deterioration, when the shores continued to be occupied; and periods of favorable climate, when the shores were deserted. It is interesting to note that even during unfavorable climatic conditions, when the hydro- logical balance of the lakes drastically changed, only a small number of settlements were directly influenced by lake level fluctuations, and people coercively displaced (Menotti 2003). If and when displacement occurred, it was more the result of economic factors triggered by crop failure. In most cases, however, people found cunning alternatives in order to cope with unexpected climate variations. This prompted a series of environmental crises, which influenced the whole of the surrounding ecosystem.

Surprisingly enough, favorable climatic conditions also caused similar economic 'disasters', as a result of overexploitation of the environment and poor natural resource management. 


\section{The lake-dwelling chronology}

The lake-dwelling tradition in the northern CircumAlpine region started at the end of the fifth Millennium $\mathrm{BC}$ and ended in the second half of the seventh century BC (Menotti 2001a; 2004). But, as much as we would like to see it as homogeneous in terms of human occupation, archaeological evidence argues for a marked discontinuity (Suter, Hafner and Glauser 2005.18). In fact, periods of occupation alternated with periods of abandonment, with the latter being caused by environmental as well as cultural factors, and sometimes a combination of both.

Magny (1995; 2004), for instance, shows that there is a plausible correlation between climate and lakedwelling occupational patterns. Periods of favorable climate coincide with periods of lake-dwelling occupation, whereas abandonment is the result of climate deterioration (Fig. 1). Pétrequin and Bailly (2004), on the other hand, argue that the relationship between climate and lake shore occupation does not always work. There are in fact periods when the climatic conditions in the lacustrine environment were favorable, but the lake shores were not settled.

For instance, short-term deteriorations in the climate in the first half of the $37^{\text {th }}$ and $36^{\text {th }}$ centuries $\mathrm{BC}$ had little impact on lake shore occupation. The one which occurred in the $34^{\text {th }}$ century BC, on the other hand, was more distinct, although some lakes (especially in the western part of Switzerland) continued to be occupied. Interestingly enough, during periods of favorable climate (c. 3500-3450 BC and 3300-3250 BC), the shores were completely deserted throughout the northern $\mathrm{Al}-$ pine region (Hafner and Suter 2000). A similar situation, but in a much larger scale, is found between $c .2400$ and 1800 BC, when, apart from very sporadic examples, the lake shores were not occupied at all.

Not only have archaeologists attempted to bridge the occupational gaps (Menotti 2003; 2004), but they have also tried to give plausible explanations as to why the shores were not settled during favorable climatic conditions (Pétrequin et al. 2002; Arbogast et al. 2006), or were occupied during climatic deterioration.

\section{Direct influence of climate deterioration: the} 'lake level fluctuation hypothesis'

Climate deterioration could have a direct impact on lacustrine settlements. An increase in humidity and precipitation could, in fact, influence the delicate hydrological balance of the lakes, causing water levels to fluctuate, hence affecting those lake villages located immediately next to the water. Of course, the extent to which the lake transgressions influenced prehistoric lacustrine settlements depended upon a variety of factors, from the size, morphology and hydrological sensitivity of the lake (Magny 1992), to the typology and location of the dwellings (Menotti 2001b). Lake Constance is known as one the most sensitive lakes in the northern Circum-Alpine region. Its normal seasonal water level fluctuations vary as much as three metres between winter (the lowest) and early summer, and/or early autumn (the highest). Abrupt changes in climatic conditions affect the lake even more, forcing people to abandon their houses situated too close to the water. In fact, the archaeological records of some excavated lacustrine villages show transgressions occurring during, and soon after, the occupation. These transgressions might have indeed been the cause of abandonment (see, for instance, Arbon-Bleiche 3 - Neolithic; and Arbon-Bleiche 2 - Bronze Age on Lake Constance, Switzerland) (Jacomet, Leuzinger and Schibler 2004; Hochuli 1994; Menotti 2001a). Lake level fluctuations were also witnessed on less sensitive

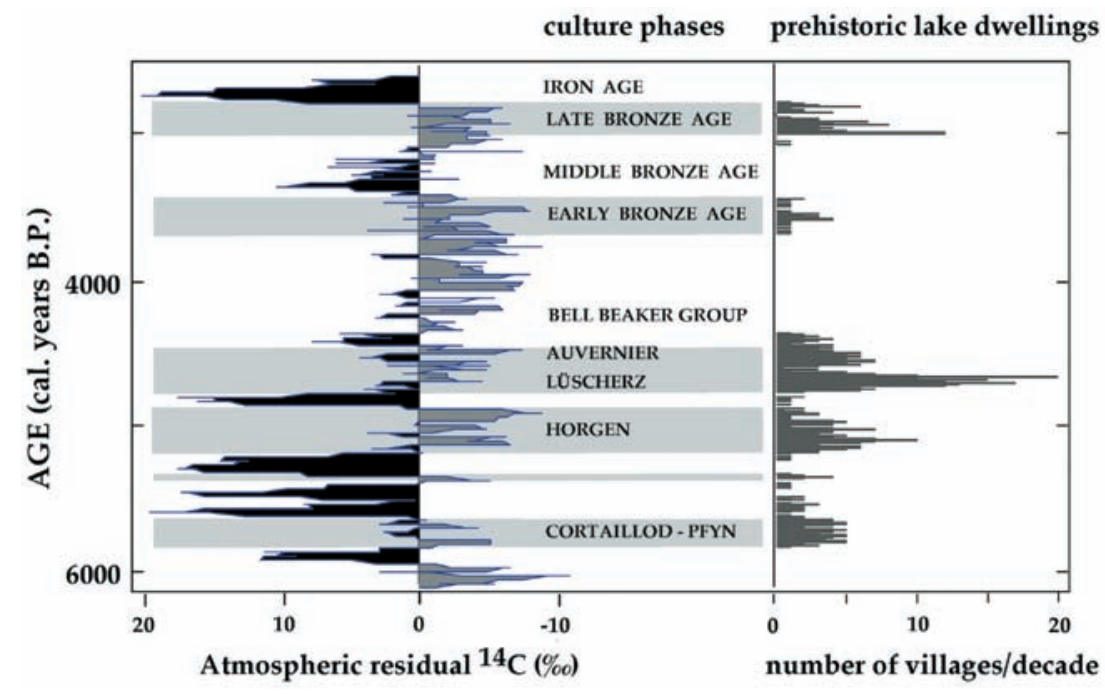

Fig. 1. Correlation between atmospheric residual 14 C variations (+ unfavourable climatic conditions; - Favorable climatic conditions) and lakeshore settlement occupations in the western part of the Circum-Alpine region (after Magny 2004). 
lakes and even on shrinking morainic lakes, such as Lake Feder (Siedlung-Forschner) in Germany (Schlichtherle and Wahlster 1986), and Lake Carera (Fiavé), Italy (Perini 1987).

Scholars have been trying to gauge the extent to which these sudden and abrupt transgressions might have affected villages and their surroundings. As pointed out above, the

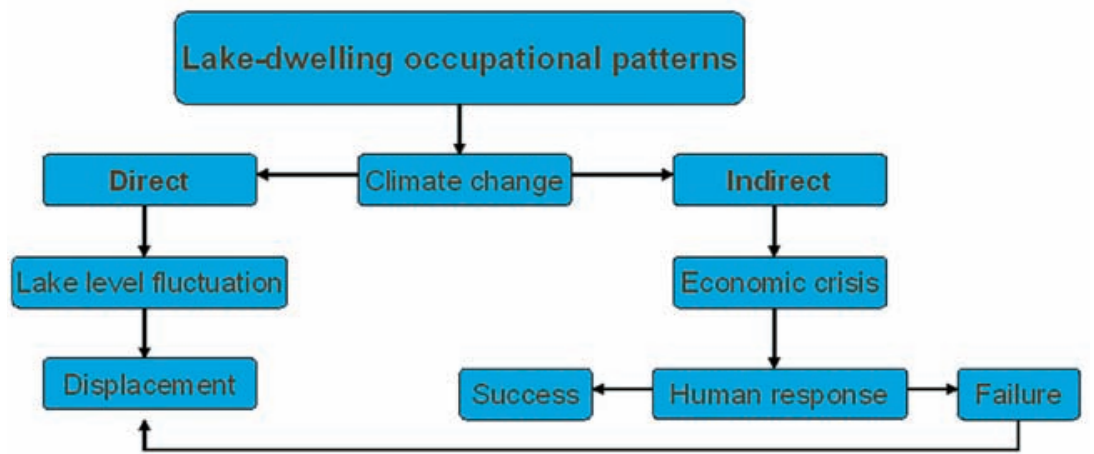

Fig. 2. Direct and indirect influence of climate change on lake-dwelling occupational patterns. severity of the impact depended on a number of factors. Some villages had to be evacuated almost immediately, others later on, as a result of economic crises triggered by extensive flooding over the nearby agricultural land (Fig. 2). Severe displacements of more inland activities occurred quite rarely, and also in those cases, the lake-dwellers maintained vital connections with the lakes (Menotti 2003).

\section{Climate influence on lake shore activities}

\section{Bad climate occupation}

Although the majority of lake-dwelling activities coincided with periods of favorable climate, there were phases when the lake shores were settled despite evidence of climate deterioration. This could depend on a variety of factors: lake shore morphology, settlement location and, of course, cultural choices. However, even if these factors allowed the lake-dwellers to occupy the very proximity of the lakes, climate deterioration might have had negative influence on the economy, as a result of crop failures. Historical records show the extent to which bad climate influences agricultural activities, depending on the season in which the bad weather occurs. It has been noted, for instance, that cold and wet summers have been the main causes of major crop failures in the Alpine region and surroundings (Pfister 2001).

\section{Good climate occupational hiatus}

Favorable climatic conditions equal lake shore activity! However, it is also quite common that shores were not settled (or even abandoned) during phases of good climate. Looking at the lake-dwelling occupational patterns from the Neolithic to the Iron Age in the northern Alpine region, one can easily spot this apparently unusual phenomenon (see the chronology section above). Possible explanations are excessively high summer temperatures and prolonged periods of drought, which, especially in areas where the soil is not very fertile, may cause crop failure. A convincing example comes from the Middle Ages in Switzerland, when, in 1540, lack of precipitation from April to August, and excessive heat in the summer, caused a major drought, which had repercussions on both flora and fauna; agricultural activity was severely disrupted and a number of animals (wild and domestic) died of starvation (Glaser et al. 1999).

Another possible explanation for occupational hiatus and/or abandonment of the lake shores might be linked to demography and overexploitation of the environment (see below).

\section{Human responses to subsistence crises}

Whether caused by favorable or unfavorable climatic conditions, economic and subsistence crises linked to crop failure had enormous repercussions on the lake shore environment, and the entire ecosystem of the northern Circum-Alpine region. The insufficiency of staple food forced the lake-dwellers to seek alternative nutritional sources to compensate for their low-calorie diet. As a result, hunting activity increased in some lacustrine areas. Interestingly enough, this increase occurs during bad as well as good climatic conditions, proving that it is mainly linked to the need for a higher-calorie diet (Arbogast et al. 2006). More hunting activity had, of course, negative repercussions on the fauna. Archaeozoological evidence, for instance, shows that red deer almost faced extinction in the Zurich area between 3660 and 3600 BC (Schibler 2004; Schibler et al. 1997). This is also confirmed by the LSI (Logarithmic Size Indices) on red deer bones; in fact, a decrease in LSI values (more hunting) is noticed in the above-mentioned time span, as opposed to the increase (less hunting) occurring between 3200 and $3000 \mathrm{BC}$, and between 2700 and $2500 \mathrm{BC}$ (Fig. 3). It has to be pointed out, however, that even within these periods there were phases of intensive hunting activity, but they were probably too short to influence the animal population size. 
More hunting was not the only alternative adopted by the lakedwellers to compensate for the lack of cereals, but there was also a noticeable increase in gathering (mainly plants and fruits). Evidence of this comes from the $37^{\text {th }}$ century lake village of Zurich-Mozartstrasse, Switzerland, where a fairly high proportion of hazelnuts was found in layers 4 and 5 , which also contained a high number of wild animal bones and low quantities of cereals (Brombacher and Jacomet 1997).

Lake shore abandonment might also have been caused by demographic expansion linked to mi-

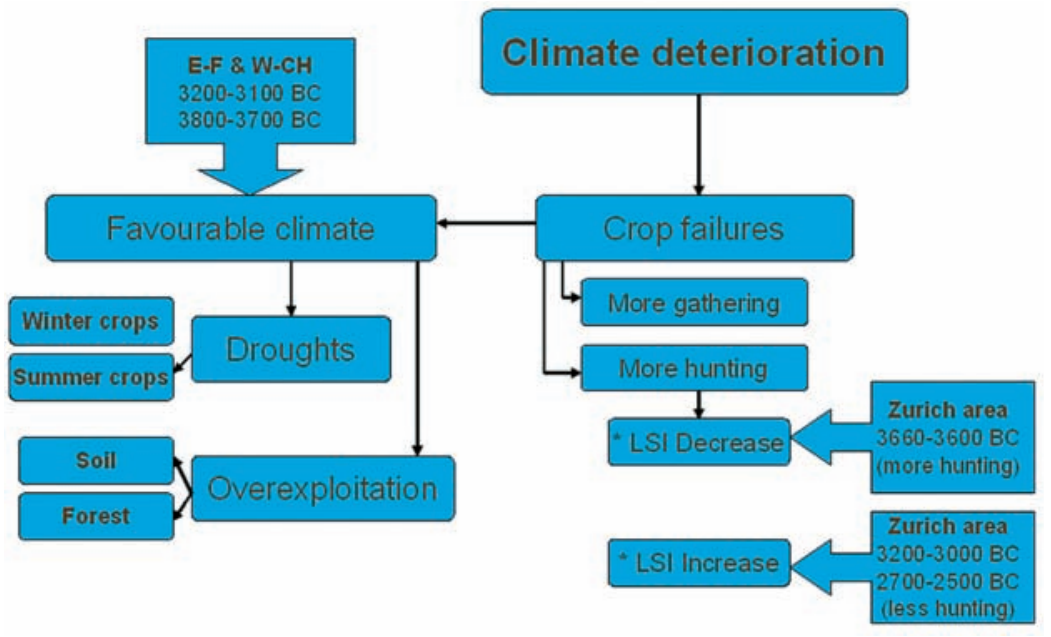

Fig. 3. Negative effects of both favorable und unfavorable climatic conditions on crop cultivation in the northern Circum-Alpine region lake-dwelling tradition (Legend: * LSI = Logarithmic Size Indices; E-F $=$ Eastern France $; \mathrm{W}-\mathrm{CH}=$ Western Switzerland). grations, and environment overexploitation. A good example is that of the Neolithic lake-dwellings at Chalain (France), which, possibly due to the influx of external cultural groups (the Eastern-Swiss Horgen groups, South-west Ferrieres groups and northwestern groups from the Saône Plain), experienced a demographic increment between 3200 and 3000 BC (Pétrequin, Magny and Bailly 2005; Arbogast et al. 1996). This triggered a series of actions, such as an increase in hunting activity (due to a higher demand for meat), overexploitation of cultivable land and the felling of primary forest trees for house building material. A combination of all the above-mentioned factors was probably what forced the lake-dwellers to move to other areas such as the Lake Clairvaux region, in search for more available natural resources (Arbogast et al. 2006).

\section{Conclusions}

The fascinating discontinuity in the Neolithic and Bronze Age lake-dwelling occupations in the northern slopes of the Circum-Alpine region of central Europe has triggered a number of questions on past human-environment interaction. Seeking plausible explanations, scholars have sometimes encountered inexplicable riddles which, reach far beyond rationality. Fair climate does not necessarily mean occupation, as much as bad one is not essentially linked to abandonment! Climate change certainly influences and transforms the environment, which itself, of course, affects humans. We have seen how the imbalanced hydrology of a lacustrine region could trigger significant lake level fluctuations. However, these water transgressions have little physical impact on the settlements themselves, in terms of flooding of the habitable area and consequent abandonment. More significant repercussions are linked to economic and subsistence crises resulting from crop failure. In order to compensate for a low-calorie diet caused by a lack of staple food, lake communities sought new nutritional alternatives outside the agricultural sphere (e.g. plant and fruit gathering, and especially hunting). As a result, overexploitation of the environment, resulting from these activities altered the natural habitat and the entire ecosystem, seriously affecting wild fauna.

Furthermore, the natural environment could also have been affected and changed by cultural phenomena, which were not necessarily triggered by climate change. In fact, we have seen how demographic growth, possibly incremented by migratory relocations, may have had similar negative effects on the environment. Higher demand for meat, led to over-hunting and possible wild animal species extinction; or overexploitation of woodlands, (including primary forests) due to a higher demand for house construction material, resulted in severe deforestation, with consequent soil erosion.

Whether triggered by natural or cultural factors, human responses to climate variability are always reflected in the environment. The severity of the consequences triggered by human responses is difficult to gauge, for they are the result of a causative chain of events. The final outcome, either in the form of success (in coping with the crisis and the permanence in the area), or defeat (abandonment and displacement) does not depend on the environment itself, but mainly on people's management skills. 
First of all, I would like to thank Prof. Budja for inviting me to the $15^{\text {th }}$ Neolithic Seminar, which he organised marvellously, and from which this publication originated. I am also very grateful to Stefi Jacomet and Jörg Schibler for providing me with vital insights on this fascinating research topic, especially concerning archaeobotany and archaeozoology.

\section{$\therefore$}

\section{REFERENCES}

ARBOGAST R-M., MAGNY M. and PETREQUIN P. 1996. Climat, cultures céréalières et densité de population au Néolithique: le cas des lacs du Jura français de 3500 à 2500 av. J.C. Archäologisches Korrespondenzblatt 6: 121-144.

ARBOGAST R-M., JACOMET S., MAGNY M. and SCHIBLER J. 2006. The significance of climate fluctuations for lake level changes and shifts in subsistence economy during the Late Neolithic (4300-2400 BC) in Central Europe. Vegetation History and Archaeobotany 15(4): 403-418.

BROMBACHER C. and JACOMET S. 1997. Ackerbau, Sammelwirtschaft und Umwelt: Ergebnisse archäobotanischer Untersuchungen. In J. Schibler, H. Hüster-Plogmann, S. Jacomet, C. Brombacher, E. Gross-Klee and A. Rest-Eicher (eds.), Ökonomie und Ökologie neolithischer und bronzezeitlicher Ufersiedlungen am Zürichsee. Ergebnisse der Ausgrabungen Mozartstrasse, Kanalisationssanierung Seefeld, AKAD/Pressehaus und Mythenschloss in Zürich. Monographien der Kantonsarchäologie 20. Zurich: 220-279.

GLASER R., BRAZDIL R., PFISTER C., DOBROVOLNY P., BARRIENDOS VALVE M. , BOKWA A., CAMUFFO D., KOTYZA O., LIMANOWKA D., RACZ L. and RODRIGO F.S. 1999. Seasonal temperature and precipitation fluctuations in selected parts of Europe during the sixteenth century. Climate Change 43: 169-200.

HAFNER A. and SUTER P.-J. 2000. 3400: die entwiklung der Bauerngesellschaften im 4. Jahrtausend v.Chr. am Bielersee. Berner Lehrmittel- und Medienverlag, Bern.

HOCHULI S. 1994. Arbon-Bleiche. Die neolithischen und bronzezeitlichen Seeufersiedlungen: Ausgrabungen 1985-1991. Amtes für Archäologie des Kantons Thurgau, Frauenfeld.

JACOMET S. 2004. Archaeobotany. A vital tool in the investigation of lake-dwellings In F. Menotti (ed.), Living on the lake in prehistoric Europe. 150 years of lake-dwelling research. Routledge, London: 162-177.

JACOMET S., LEUZINGER U. and SCHIBLER J. 2004. Die neolithische Seeufersiedlung Arbon Bleiche 3. Umwelt und Wirtschaft. Archäologie im Thurgau 12. Frauenfeld.
MAGNY M. 1993. Solar influences on Holocene climatic changes illustrated by correlations between past lake-level fluctuations and the atmospheric ${ }^{14} \mathrm{C}$-record. Quaternary Research 40: 1-9.

1995. Une histoire du climat. Des derniers mammouths au siècle de l'automobile. Errance, Paris.

2004. The contribution of palaeoclimatology to the lake-dwellings. In F. Menotti (ed.), Living on the lake in prehistoric Europe. 150 years of lake-dwelling research. Routledge, London: 132-143.

MENOTTI F. 2001a. 'The missing period': Middle Bronze Age lake-dwellings in the Alps. BAR IS S968. Archaeopress, Oxford.

2001b. The Pfahlbauproblem and the history of the lake-dwelling research in the Alps. Oxford Journal of Archaeology 20(4): 319-328.

2003. Cultural response to environmental change in the Alpine lacustrine regions: the displacement model oxford Journal of Archaeology 22(4): 375-396.

(ed.) 2004. Living on the lake in prehistoric Europe. 150 years of lake-dwelling research. Routledge, London.

PERINI R. 1987. Scavi archeologici nella zona palafitticola di Fiave'-Carera (parte seconda). Servizio Beni culturali della Provincia di Trento. Trento.

PÉTREQUIN P. and BAILLY M. 2004. Lake-dwelling research in France: from climate to demography. In F. Menotti (ed.), Living on the lake in prehistoric Europe. 150 years of lake-dwelling research. Routledge, London: 3649.

PETREQUIN P., ARBOGAST R. M., BOURQUIN-MIGNOT C., DUPLAIX A., MARTINEAU R., PETREQUIN A. M. and VIELLET A. 2002. Le mythe de la stabilité: déséquilibres et réajustements d'une communauté agricole néolithique dans le Jura français, du 32e au 30e siècle av. J.-C. In H. Richard and A. Vignot (eds.), Equilibres et ruptures dans les écosystèmes durant les 20 derniers millénaires: durabilité 
et mutation. Actes du colloque international de Besançon (2000), Annales Littéraires de l'Université de FrancheComté, Série Environnement, Sociétés et Archéologie 3. Les Belles Lettres, Paris: 175-190.

PETREQUIN P., MAGNY M. and BAILLY M. 2005. Habitat lacustre, densité depopulation et climat. L'exemple du Jura français. In P. Della Casa and M. Trachsel (eds.), WES'04 -Wetland economies and societies. Proceedings of the International Conference in Zurich, 10-13 March 2004. CRONOS. Zurich: 143-168.

PFISTER C. 2001. Klimawandel in der Geschichte Europas. Zur Entwicklung und zum Potenzial der historischen Klimatologie. Österreichische Zeitschrift für Geschichtswissenschaften 12(2): 7-42.

SCHIBLER J., HÜSTER-PLOGMANN H., JACOMET S., BROMBACHER CH., GROSS-KLEE E., RAST-EICHER A. 1997. Ökonomie und Ökologie neolithischer und bronzezeitlicher Ufersiedlungen am Zürichsee. Ergebnisse der Ausgrabungen Mozartstrasse, Kanalisationssanierung Seefeld,
AKAD/Pressehaus und Mythenschloss in Zürich. Monographien der Kantonsarchäologie Zürich 20. Zurich.

SCHIBLER J. 2004. Bones as a key for reconstructing the environment, nutrition and economy of the lake-dwelling societies. In F. Menotti (ed.), Living on the lake in prehistoric Europe. 150 years of lake-dwelling research. Routledge, London: 144-161.

2006. The economy and environment of the $4^{\text {th }}$ and $3^{\text {rd }}$ millennia $\mathrm{BC}$ in the northern Alpine foreland based on studies from animal bones. Environmental Archaeology 11: 49-64.

SCHLICHTHERLE H. and WAHLSTER B. 1986. Archäologie in Seen und Mooren. Konrad Theiss Verlag, Stuttgart.

SUTER P. J., HAFNER A. and GLAUSER K. 2005. Prähistorishe und frügeschichtliche Funde aus dem Eis - der wiederentdeckte Pass über das Schnidejoch. Archäeologie der Schweiz 28(4): 16-23. 